\title{
MORPHOLOGICAL CHARACTERISTICS, ASSESSMENT OF HYPERMOBLITYY AND PAIN THRESHOLD OF RUGBY PLAYERS
}

\author{
Joanna Trubiłko, , A, B, D Piotr Kolano, 2, B, D Elżbieta Sieńko-Awierianów, ${ }^{3, A, D}$ \\ Monika Chudecka ${ }^{3, A, C, D}$
}

\footnotetext{
${ }^{1}$ West Pomeranian University of Technology in Szczecin, Department of Physical Education and Sport, Poland

${ }^{2}$ Kolano Medic, Szczecin, Poland

${ }^{3}$ University of Szczecin, Faculty of Health and Physical Education, Institute of Physical Culture Sciences, Poland

A Study Design; ${ }^{B}$ Data Collection; ${ }^{C}$ Statistical Analysis; ${ }^{D}$ Manuscript Preparation; EFund Collection
}

\author{
Address for correspondence: \\ Monika Chudecka \\ Institute of Physical Culture Sciences, University of Szczecin \\ Al. Piastów 40 b, block 6, 71-065 Szczecin, Poland \\ Email: monikachudecka@wp.pl
}

\begin{abstract}
Ahstract Body build is an important factor in achieving success in sport. One sport that is less investigated, in terms of player morphological characteristics, is rugby $7 \mathrm{~s}$. Rugby $7 \mathrm{~s}$ with 7 players in a team was derived from the classical Rugby Union with 15 players. A team of rugby $7 \mathrm{~s}$ consists of scrum and offensive formations. As a contact sport, rugby carries the risk of numerous injuries for its players. The aim of the study was the morphological characterization and assessment of body composition, hypermobility and pain threshold of rugby players, taking into account their tasks and position on the pitch during the game. The research carried out in Kaskada Szczecin team showed that the scrum players obtained considerably higher statistically significant values of body weight, BMI, fat content percentage as well as chest depth than the offensive players, who obtained statistically significantly higher values of muscle tissue percentage. The examined rugby players had a high pain threshold, however, no statistically significant differences between both rugby formations were found in the assessment of the pain threshold. The occurrence of hypermobility in the studied group of rugby players was determined at only $3.8 \%$. Identification of potential factors such as pain threshold or hypermobility can provide additional information for trainers and physiotherapists, helping to minimize the risk of injury.
\end{abstract}

Key WOrds rugby 7s, morphological characteristics, hypermobility, pain threshold, algometry

\section{Introduction}

Body build is an important factor in achieving success in sport. Knowledge of appropriate morphological features, body proportions, which vary for each sport, facilitates the process of selection and recruitment. Issues related to athletic build have been discussed in numerous research works and scientific studies, including both representatives of individual sports and team games (Pietraszewska, 1998; Pietraszewska, Stachoń, Burdukiewicz, Andrzejewska, Sieroń, 2016; Krakowiak, Cabrić, Sokołowska, Lewandowski, 2008; Krakowiak, Lewandowski, 
Sokołowska, Čabrić, 2017). One of the less investigated sports, in terms of player morphological characteristics, is rugby 7s. This sport is derived from the classical Rugby Union that originated from football sports in the 19th century in the British Isles. The oldest written rules of the game were created in 1845 in the city of Rugby located in central England, which gave the name to the entire sport. Today, rugby associations exist in 170 countries, of which 117 are members of World Rugby. Matches are played with an oval ball.

The aim of the game is to ground the ball inside the opponent's point area behind the goal line of the pitch. In rugby, players from one team can only pass the ball backwards. If a mistake is made and the ball is thrown forward or falls out of the player's hands, the referee calls for a characteristic element of this sport called a scrum formation. The spectacularity of this sport is primarily based on the possibility of stopping the player with the ball by knocking them to the ground in an action called a "tackle". Only players who have the ball can be stopped by having their shirts, legs, arms, grabbed or body blocked. It is only permitted to tackle a player when both the legs are on the pitch. It is also forbidden to strike, kick or tackle above the shoulder (Powała-Niedźwiecki, 1997).

Rugby 7s with 7 players in a team was derived from the classical Rugby Union with 15 players in a team. In 2016, Rugby 7s was added to the Summer Olympic Games programme. The Polish national team takes part in competitions organized by Rugby Europe.

The rugby rules regarding seven and fifteen player teams are mostly similar, with changes designed to adapt the game to fewer players on the pitch. The match of Rugby $7 \mathrm{~s}$ requires a great deal of physical effort, and therefore comprises 2 halves of 7 minutes. Moreover, due to the shorter time, matches in this type of rugby are conducted in the form of tournaments. In Rugby 7s, the team that scored points starts the game, while in Rugby Union the team that lost these points begins. The formation of the scrum in rugby sevens includes 3 players, and 8 in Rugby Union.

In 2016, Rugby 7s was added to the Summer Olympic Games programme. The Polish national team takes part in competitions organized by Rugby Europe. A team of rugby 7s, the type of game practiced in Poland, has 7 players on the pitch. It consists of scrum and offensive formations. Scrums in Rugby 7s consist of 3 players: the right and left props of the scrum and a hooker. The props are usually the tallest and strongest players on the pitch, whose main task is to hold the scrum and lift up the jumping players. The hooker is the most important player in the formation, as he brings the scrum together, is responsible for coordinating it and playing a set-piece fragment of the game, starting the game from the lineout, scooping back the ball in the scrum, is active in the defensive game, and often tackles. Behind the formation of the scrum there are offensive players, namely: scrum-half, fly-half, centre player and wing player. The scrum-half throws the ball into the scrum, starts most of their team's actions, and is greatly responsible for the team's tactics. Tasks of a fly-half include finding and exploiting gaps in the defence of the opponent. They are the best kickers on the pitch, set the pace of the game, and kick the ball forward to the centres or forward. Centre players have important roles in attack and defence. In the case of the latter, they often interrupt the opponent's attack, while in offence, they get the ball, break the defensive lines, pass the ball on, and overtake defensive players. Wing players, who most often are responsible for scoring "tries", are the last line of defence for their team (https://www.pzrugby.pl).

Rugby is a sport that is becoming increasingly popular in Poland. As a contact sport, it carries the risk of numerous injuries between players (Trzepizur, Bielecki, Jędrusik-Pawłowska, Cieślik-Bielecka, 2016). Therefore, it is extremely important to look for potential factors that may reduce the risk of injury. The aim of the study was the morphological characterization and assessment of body composition, hypermobility and pain threshold of rugby players, taking into account their tasks and position on the pitch during the game 


\section{Materials and Methods}

The research covered players practicing RUGBY in the Kaskada Szczecin team, who take part in the Polish Rugby 7s League and Polish Rugby 7s Cup. The team also trains players appointed to the Polish national team in Rugby 7s. A positive opinion of the Bioethics Committee No. 10/KB/VI/2018 of June 21, 2018, was obtained for the conducted research. The study was performed in compliance with the Declaration of Helsinki.

The surveyed players were of chronological age from 18 to 35 years, while their professional experience ranged from 2 to 11 years. The players were divided into 2 group-formations according to the tasks and positions they occupy on the pitch during the game (Żyła, Stachura, Różańska, 2014).

Group 1 are SCRUM players (props, hooker), who are responsible for creating the scrum formation, i.e. starting a set-piece of the game. Group 2 are OFFENSIVE players (scrum-half, fly-half, centre and wing players), whose task is to play the ball and move it into the opponent's goal area, i.e. to score a try.

Information on the chronological age and professional experience of each player was collected. Morphological features were measured in accordance with the principles adopted in Z. Drozdowski's anthropometry (1992): body height (BV), body weight, torso length (sst-sy), upper limb length (a-da), lower limb length (sy-B), shoulder width (a-a), chest width (thl-thl), chest depth (ths-xi), hip width (ic-ic), shoulder circumference, thigh circumference, chest circumference.

Body composition measurements of body fat percentage, skeletal muscle percentage, body mass index BMI and PPM were performed using an Omron BF 511 body composition analyser.

Moreover, joint hypermobility was also assessed using the Beighton scale (Beighton, Grahame, Bird, 2012), consisting of an analysis of the mobility of selected peripheral joints and the spine. For each activity performed the patient was assigned points on a scale of $0-1$. Obtaining at least 4 points indicated joint hypermobility. Movement was assessed for the right and left sides of the body. During diagnostics carried out with this scale, the player performed the following tasks: passive dorsiflexion of the fifth MCP (metacarpophalangeal) joint $\geq 90^{\circ}$; the ability to bring the thumb to the forearm; elbow hyperextension $\geq 10^{\circ}$; knee joint hyperextension $\geq 10^{\circ}$; the ability tp place the hands flat on the ground while bending forward and keeping the knees straight (Beighton et al., 2012).

In the study group, pressure pain threshold (PT) was assessed using a pressure algometer manufactured by Quirumed. Algometry is a quantitative method for the assessment of tenderness that is commonly used in clinical practice (Chesterton, Sim, Wright, Foster, 2007). PT is defined as the minimal amount of pressure where the pressure sensation first becomes painful (Vanderweeën, Oostendorp, Vaes, Duquet, 1996). The PPT of the participants was measured by gradually increasing the pressure exerted by the head of the algometer, which was placed at an angle of 90 degrees, with a speed of $100 \mathrm{~g} / \mathrm{s}$ until the pressure sensation first became painful (the participants were instructed to say 'stop' when they felt a painful sensation). A mean for three measurements was then calculated and used for the main analysis. A 30-second rest between each measurement was allowed. PPT was measured: the 1st dorsal interossei of the left hand (PPT1) and the tibialis anterior muscle (PPT2).

Descriptive statistics were used for material analysis, and Student's $T$ test was used to assess the significance of differences in the parameters studied, assuming significance at the level of $p<0.05$. 


\section{Results}

Descriptive characteristics (values of arithmetic means and standard deviations) of chronological age, training experience and the analysed morphological features, as well as body composition, for all the rugby players were broken down by formation and presented in Table 1. It also includes the results of the significance of differences (Student's T test) for $p<0.05$ in the tested parameters in groups of players, taking into account their tasks and position on the pitch during the game. Statistically significantly higher values, such as body weight, chest depth, BMI index and fat percentage, were recorded for the scrum players as opposed to the offensive players, who obtained statistically significantly higher values for the percentage of muscle tissue.

Table 1. Descriptive characteristics of the analysed parameters of rugby players (in total and divided into formations) and the results of the test of significance of differences in the examined features between players of selected formations

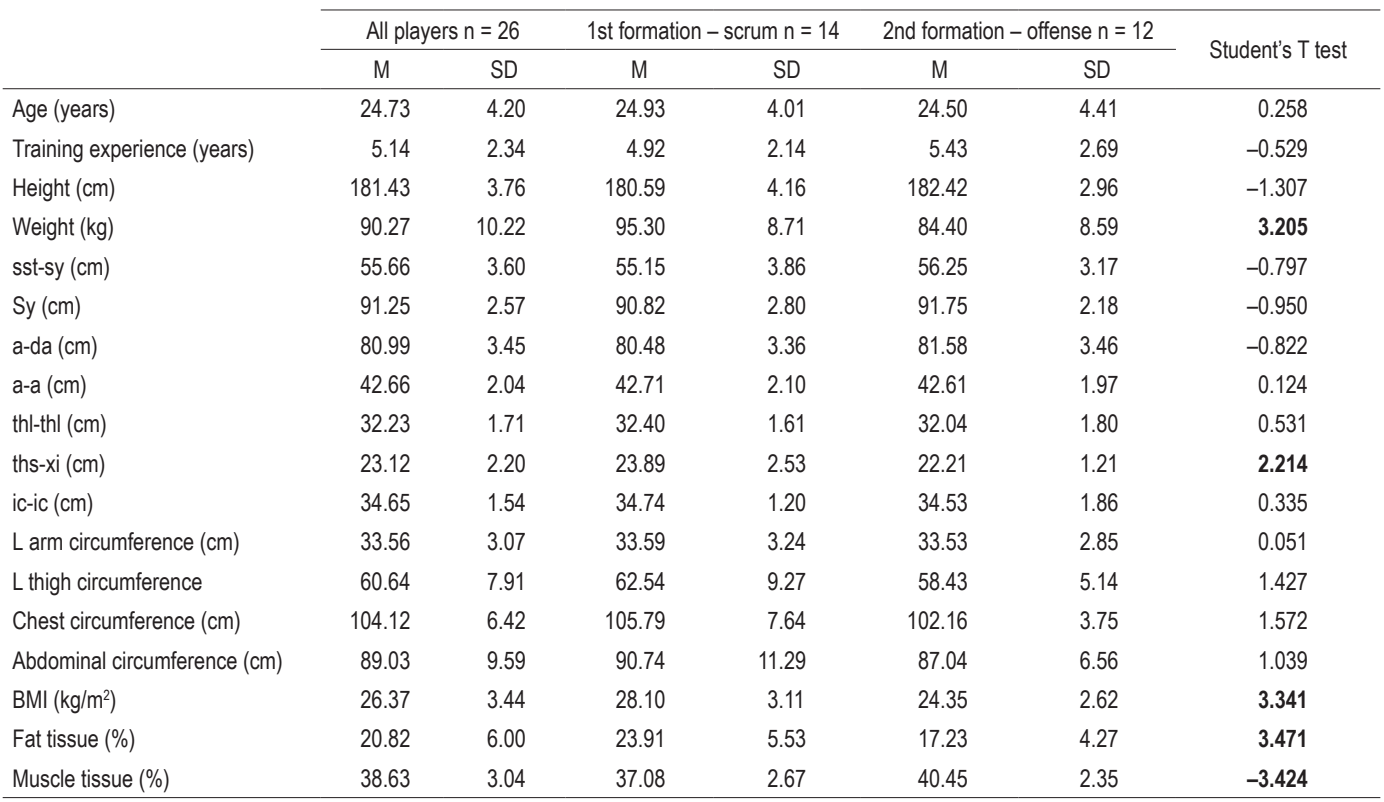

Difference statistical significance for $p<0.05$ in bold.

The results of Beighton's hypermobility assessment of rugby players in total, and taking into account the division into formations, are presented in Table 2. Accordingly, only one player had JHS, i.e. obtained at least 4 points.

Table 2. Beighton's results of hypermobility assessment of rugby players in total and taking into account the division into formations

\begin{tabular}{lcccc}
\hline \multirow{2}{*}{ Hypermobility } & \multicolumn{2}{c}{ All players $\mathrm{n}=26$} & 1st formation - scrum $\mathrm{n}=14$ & 2nd formation - offense $\mathrm{n}=12$ \\
\cline { 2 - 5 } & $\mathrm{n}$ & $\%$ & $\mathrm{n}$ & $\mathrm{N}$ \\
\hline Occurrence of JHS & 1 & 3.8 & 1 & 0 \\
No JHS & 25 & 96.2 & 13 & 12 \\
\hline
\end{tabular}


The results of the assessment of the pain threshold of rugby players in total and taking into account the division into formations and the assessment of the significance of differences between selected formations are presented in Table 3. No statistically significant differences were found in the assessment of pain threshold on both the dorsal interossei of the left hand (PPT1) and the tibialis anterior muscle (PPT2) in the analysed groups of 2 rugby formations.

Table 3. Results of the assessment of player pain threshold and significance of differences

\begin{tabular}{|c|c|c|c|c|c|c|c|}
\hline & \multirow{2}{*}{\multicolumn{2}{|c|}{$\begin{array}{c}\text { All players } \\
n=26\end{array}$}} & \multirow{2}{*}{\multicolumn{2}{|c|}{$\begin{array}{l}\text { 1st formation - scrum } \\
n=14\end{array}$}} & \multirow{2}{*}{\multicolumn{2}{|c|}{$\begin{array}{l}\text { 2nd formation - offensive } \\
\qquad n=12\end{array}$}} & \multirow{3}{*}{ Student's T test } \\
\hline & & & & & & & \\
\hline & M & SD & M & SD & $\mathrm{M}$ & SD & \\
\hline PPT 1 (N/s) & 12.98 & 3.01 & 13.17 & 2.98 & 12.79 & 2.77 & 0.337 \\
\hline PPT 2 (N/s) & 13.42 & 3.11 & 13.92 & 2.87 & 12.92 & 2.91 & 0.879 \\
\hline
\end{tabular}

Statistical significance for $p<0.05$.

\section{Discussion}

In rugby, as in other team sports, players have different motor tasks to perform during the game. Thus, their different specializations are also closely related to the varied body build of players playing in different positions. The most intense form of work in rugby is the contact itself, which should be very dynamic and short. There are also sprints and runs, which involve passing several players by means of feints or quick contact or knocking down an opponent. All these efforts are brief, but of very high intensity, which is why players must demonstrate the development of maximum power or strength in a short period of time and repeat these efforts repeatedly in short intervals. The scrum players during the match take part in the contact phase for $14 \%$ of the time, while the offensive players only for $1.3 \%$ of the game time. Offensive players focus mainly on speed and endurance, while scrum player training regards mainly strength preparation (Gasik, Stupnicki, 2013). The tests carried out in the Kaskada Szczecin team showed considerably higher statistically significant values of body weight, BMI, fat percentage as well as chest depth for the scrum players as opposed to the offensive players. Players in the 2nd formation obtained statistically significantly higher values for the percentage of muscle tissue. When examining players from three teams of the Polish Rugby Ekstraliga, D. Pietranis, J. Janowski and K. Karpowicz (2017) showed differences in body structure between the scrum and offence formation and found that in the case of similar body height, the scrum players are characterized by a much higher body weight than the offensive players, which was also confirmed by our research.

The morphological characteristics and assessment of player body composition are an important element of selection and recruitment at the level of professional sport. However, in rugby, as well as other contact sports that carry the risk of numerous injuries, it is very important to identify as many factors as possible that determine the achievement of sports successes and can be helpful in minimizing the risk of injury.

The use of non-invasive testing methods for assessing player reactivity to stimuli - pain threshold or hypermobility can contribute to the optimization of the training process.

Pain is a specific sensation that plays a protective function, informing about the imminent damage. In the case of athletes, it indicates the limits of the physical capacity and is part of the sports experience (Pawlak, 2014). Differentiation in tolerance depending on the sport has been observed (Tajet-Foxell, Rose, 1995). In endurance sports, athletes show reduced pain sensitivity compared to strength sports (Assa, Geva, Zarkh, Defrin, 2019; Ceva, 
Defrin, 2013). The studied rugby players had a high pain threshold; however, no statistically significant differences were found in an assessment of the pain threshold in groups of 2 nd rugby formation. A higher pain threshold may help succeed in sport; however, it should be kept in mind that people with lower pain sensitivity are at risk of overload and injury (Neziri et al., 2011).

Joint hypermobility $(\mathrm{JH})$ is a condition that causes joints to move beyond their normal range of motion. Joint hypermobility syndrome (JHS) refers to a situation where four or more joints can move beyond their physiological range (Reuter, Fichthorn, 2019; Skwiot, Śliwiński, Milanese, Śliwiński, 2019). The JHS clinical diagnosis uses the Beighton point system (Beighton et al., 2012). In the examined group of 26 rugby players, JHS was diagnosed in just 1 player. While hypermobility predisposes to selected sports such as ballet or dance, in the case of rugby players, it may also be the cause of an increased risk of injury to the musculoskeletal system. The occurrence of hypermobility is statistically significantly associated with the risk of musculoskeletal disorders. This correlation has been confirmed by many scientific reports (Reuter, Fichthorn, 2019; Scheper et al., 2013; Smith, Damodaran, Swaminathan, Campbell, Barnsley, 2005; Konopinski, Graham, Johnson, Jones, 2016; Decoster, Bernier, Lindsay, Vailas, 1999; Stewart, Burden, 2004). In the case of suspicion of the existence of hypermobility, it is important to correctly diagnose and modify the training program. The incidence of hypermobility in the population of people aged $20-30$ is about 34\% (Connelly, Hakim, Davenport, Simmonds, 2015; Russek, Errico, 2016). The occurrence of hypermobility in the examined rugby players was determined only at the level of $3.8 \%$, which may indicate the correct selection for practicing this sport.

\section{Conclusion}

The complex interaction of identifiable factors determines the achievement of success in every sport. Learning as many of these factors as possible is very important for optimizing sport training, especially in sports such as rugby $7 \mathrm{~s}$, which are characterized by significant morphological diversity resulting from the motor tasks of players playing in different positions. Identification of potential factors such as pain threshold or hypermobility can provide additional information for trainers and physiotherapists, helping to minimize the risk of injury.

\section{Referenences}

Assa, T., Geva, N., Zarkh, Y., Defrin, R. (2019). The type of sport matters: Pain perception of endurance athletes versus strength athletes. Eur. J. Pain, 23, 686-696. DOI: 10.1002/ejp.1335.

Beighton, P.H., Grahame, R., Bird, H.A. (2012). Assessment of Hypermobility, Chapter 2, in Hypermobility of Joints. 4th ed. London: Springer-Verlag. DOI: 10.1007/978-1-84882-085-2.

Chesterton, L.S., Sim, J., Wright, C.C., Foster, N.E. (2007). Interrater Reliability of Algometry in Measuring Pressure Pain Thresholds in Healthy Humans, Using Multiple Raters. Clin. J. Pain., 23, 760-766. DOI: 10.1097/AJP.0b013e318154b6ae.

Connelly, E., Hakim, A., Davenport, Simmonds, J.A. (2015). A study exploring the prevalance of joint hypermobility syndrome in patients attending a musculoaskeletal triage clinic. Physiotherapy Practice and Research, 36, 43-53.

Decoster, L.C., Bernier, J.N., Lindsay, R.H., Vailas, J. (1999). Generalized joint hypermobility and its relationship to injury patterns among NCAA lacrosse players. J. Athl. Train., 34, 99-105.

Drozdowski, Z. (1992). Antropometria w wychowaniu fizycznym. Poznań: Akademia Wychowania Fizycznego.

Gasik, T., Stupnicki, R. (2013). Ocena wytrzymałości anaerobowej zawodników rugby. Zeszyty Naukowe WSKFiT, 8, 27-32.

Geva, N., Defrin, R. (2013). Enhanced pain modulation among triathletes: a possible explanation for their exceptional capabilities. Pain, 154, 2317-2323. DOI: 10.1016/j.pain.2013.06.031.

http://www.wskfit.pl/PDF/artykuly/13/13013.pdf (4.03.2019). 
https://bjsm.bmj.com/content/bjsports/30/1/53.full.pdf (4.03.2019).

https:// www.pzrugby.pl (4.03.2019).

Krakowiak, H., Cabrić, M., Sokołowska, E., Lewandowski A. (2008). Budowa i skład ciała lekkoatletów trenujących biegi krótkie. Medycyna Sportow, 24.

Krakowiak, H., Lewandowski, A., Sokołowska, E., Čabrić M. (2017). Zmiany morfologiczne u młodych wioślarzy w rocznym cyklu treningowym. Medical and Biological Sciences, 21/3.

Konopinski, M., Graham, I., Johnson, M.I., Jones, G. (2016). The effect of hypermobility on the incidence of injury in professional football: A multi-site cohort study. Phys. Ther. Sport., 21, 7-13. DOI: 10.1016/j.ptsp.2015.12.006.

Neziri, A.Y., Scaramozzino, P., Andersen, O.K., Dickenson, A.H., Arendt-Nielsen, L., Curatolo, M. (2011). Reference values of mechanical and thermal pain tests in a pain-free population. Eur J Pain, 15 (4), 376-83. DOI: 10.1016/j.ejpain.2010.08.011.

Pawlak, M. (2014). Ból w sporcie-aktualne wyzwania dla teorii i praktyki. Forum Zaburzeń Metab. 5, 158-164.

Pietranis, D., Janowski, J., Karpowicz, K. (2017). Charakterystyka zdolności siłowych w Rugby Union 15 na poziomie mistrzowskim. In: A. Makarczuk, A. Maszorek-Szymala, J.E. Kowalska, A. Kaźmierczak (ed.), Biospołeczne uwarunkowania uczestnictwa w kulturze fizycznej i zdrowotnej osób w różnym wieku (pp. 229-242). Łódź: Wydawnictwo Uniwersytetu Łódzkiego. DOl: 10.18778/8088-329-1.17.

Pietraszewska, J. (1998). Zróżnicowanie morfologiczne zawodników różnych dyscyplin sportowych. Studia i Monografie. Wrocław: Akademia Wychowania Fizycznego.

Pietraszewska, J., Stachoń, A., Burdukiewicz, A., Andrzejewska, J., Sieroń, A. (2016). Budowa ciała siatkarzy na różnych poziomach sportowych. Journal of Education, Health and Sport, 6.

Powała-Niedźwiecki, M. (1997). ABC kibica rugby. Krajowa Agencja Wydawnicza.

Reuter, P.P., Fichthorn, K.R. (2019). Prevalence of generalized joint hypermobility, musculoskeletal injuries, and chronic musculoskeletal pain among American university students. PeerJ, 7, e7625. DOl: 10.7717/peerj.7625. eCollection 2019.

Russek, L.N., Errico, D.M. (2016). Prevalence, injury rate and, symptom frequency in generalized joint laxity and joint hypermobility syndrome in a "healthy" college population. Clinical Rheumatology. 35 (4), 1029-1039.

Scheper, M.C., De Vries, J.E., De Vos, R., Verbunt, J., Nollet, F., Engelbert, R.H. (2013). Generalized joint hypermobility in professional dancers: a sign of talent or vulnerability? Rheumatology, 52, 651-658. DOI: 10.1093/rheumatology/kes220.

Skwiot, M., Śliwiński, G., Milanese, S., Śliwiński, Z. (2019). Hypermobility of joints in dancers. PLoS One, 14 (2), 22. DOI: 10.1371/ journal.pone.0212188.

Smith, R., Damodaran, A.K., Swaminathan, S., Campbell, R., Barnsley, L. (2005). Hypermobility and sports injuries in junior netball players. Br. J. Sports Med., 39, 628-631. DOI: 10.1136/bjsm.2004.015271.

Stewart, D.R., Burden, S.B. (2004). Does generalised ligamentous laxity increase seasonal incidence of injuries in male first division club rugby players? Br. J. Sports Med., 38, 457-460. DOI: 10.1136/bjsm.2003.004861.

Tajet-Foxell, B., Rose, F.D. (1995). Pain and pain tolerance in professional ballet dancers. Br. J. Sports Med., 29, 31-34.

Trzepizur, M., Bielecki, T., Jędrusik-Pawłowska, M., Cieślik-Bielecka, A. (2016). Analiza obrażeń u zawodników trenujących rugby. J. Orthop.Trauma Surg. Relat. Res., 4 (41), 028-031.

Vanderweeën, L., Oostendorp, R.A.B., Vaes, P., Duquet, W. (1996). Pressure algometry in manual therapy. Man. Ther., 1, 258-265. DOI: $10.1054 /$ math.1996.0276.

Żyła, K., Stachura, J., Różańska, D. (2014). Assessment of dietary intake and anthropometric parameters among rugby union players. Central European Journal of Sport Sciences and Medicine, 8 (4), 35-46.

Cite this article aS: Trubiłko, J., Kolano, P., Sieńko-Awierianów, E., Chudecka, M. (2020). Morphological Characteristics, Assessment of Hypermobility and Pain Threshold of Rugby Players. Central European Journal of Sport Sciences and Medicine, 3 (31), 107-113. DOI: 10.18276/cej.2020.3-09. 